Educational Research for Social Change (ERSC)

Volume: 5 No. 2, September 2016

pp. $65-80$

ersc.nmmu.ac.za

ISSN: 2221-4070

\title{
Pedagogical Habitus Engagement: Teacher Learning and Adaptation in a Professional Learning Community
}

\author{
Jennifer Feldman \\ Stellenbosch University \\ jennf2103@gmail.com
}

\begin{abstract}
Situated within the context of teaching in post apartheid South Africa, this article discusses the establishment and functioning of a professional learning community (PLC) that was constituted to generate pedagogical learning and adaptation among practicing teachers in consonance with a socially just teaching orientation. Drawing on the thinking tools of Bourdieu, the article offers a view of PLCs as a form of "habitus engagement" that engages with teachers' firmly established pedagogical identities, their "pedagogical habitus," to effect adaptation and change in their classroom pedagogy. The exemplifying basis of this article is empirical data drawn from a 2-year PLC process where teachers from different school contexts collaborated to find ways to conceptually and pragmatically shift and change their pedagogy. The article highlights both the limits and possibilities of teachers' pedagogical change and concludes by arguing that the ongoing, reflexive, and dialogical PLC process, as a form of habitus engagement, holds the potential to challenge, adapt, and shift teachers' pedagogical habitus to conceptually and pragmatically include a more socially just teaching orientation in their classroom pedagogy.
\end{abstract}

Keywords: Professional learning community, teacher learning, social justice, funds of knowledge, Bourdieu, pedagogical habitus

Copyright: (C) 2016 Feldman

This is an open access article distributed under the terms of the Creative Commons Attribution Non-Commercial License, which permits unrestricted non-commercial use, distribution, and reproduction in any medium, provided the original author and source are credited.

\section{Please reference as:}

Feldman, J. (2016). Pedagogical Habitus Engagement: Teacher Learning and Adaptation in a Professional Learning Community. Educational Research for Social Change, 5(2), 65-80. http://dx.doi.org/10.17159/2221-4070/2016/v5i2a5 


\section{Introduction ${ }^{1}$}

This article is based on the premise that good teachers and their pedagogies make the greatest difference to students' learning in schools, particularly those from disadvantaged backgrounds (Coleman et al., 1966; Hayes, Mills, Christie, \& Lingard, 2006, p. 1). The Coleman report on Equality of Educational Opportunity (Coleman et al., 1966), which investigated why public schools in America were not offering equal educational opportunity for all individuals, states that while context remains an overriding factor in determining schooling success, the extent to which students feel they have some form of control or agency over their learning makes more of a difference than all other school factors put together. Situated within the South African teaching context, and based on the understanding that teachers and their pedagogies play a significant role in improving the learning outcomes for all students, this article focuses on teacher learning and adaptation within a professional learning community (PLC).

Central to this discussion is the positioning of teachers as professionals within the current school landscape. This positioning of teachers places them as agents of change within the regulative institutional contexts and scripted curriculum mandated by the South African Department of Education that frame their working contexts. Fataar (2012) argued that the focus on policy discourse that has dominated current educational developments both locally and internationally has eroded teacher autonomy. Consequently, the restrictive curriculum policy orientation (Spreen \& Vally, 2010) that currently frames teachers' pedagogy has struggled to leverage an engaging pedagogical platform in schools.

The establishment of a PLC, which forms the empirical basis of this article and which is discussed in more depth below, was an attempt to provide an opportunity for teachers from different school contexts to dialogue together with a focus on pedagogical adaptation and innovation in light of the demands and challenges of the South African National Curriculum Assessment Policy Statements (CAPS). The PLC was motivated by a desire to develop a space for professional learning to expand the participating teachers' pedagogical repertoires. The focus of the PLC was on providing an opportunity for the teachers from different school contexts to involve themselves in teacher learning and critical reflexivity about their pedagogy.

In support of a richer notion of classroom teaching and learning, this article presents the logic for a PLC focus that draws on Nancy Fraser's (1997) conceptualisation of social justice and the funds of knowledge (FoK) approach (Moll, Amanti, Neff, \& González, 1992). Fraser's social justice approach emphasises the need to consider the tension between the redistribution of the school knowledge code currently encoded in the CAPS, recognition of student sociocultural constructions of identity, and a representation within school knowledge of the students' lifeworld knowledges or their funds of knowledge. The FoK approach capitalises on household and community resources of knowledge and offers a socially just alternative that "far exceeds the rote-like instruction" that children commonly encounter in schools (Moll et al., 1992, p. 132). This approach encourages teachers discursively and practically to reach beyond the received curriculum and to mobilise the students' lived knowledge as a resource and asset in classroom work.

\footnotetext{
1 This article is based on research that was compiled for a doctoral dissertation titled Eliciting Pedagogical Learning of Teachers in a Professional Learning Community (Feldman, 2016). Sections of this article are taken from the dissertation that drew together insights gained from teachers collaborating together over a 2-year period in a professional learning community with a focus on a social justice approach to teaching and learning. The dissertation includes two published articles and two book chapters: Fataar, A., \& Feldman, J. (in press); Fataar, A., \& Feldman, J. (2016); Feldman, J., \& Fataar, A. (2014); Feldman, J., \& Fataar, A. (2016).
} 
The focus of the PLC dialogue was an attempt to bring Fraser's conceptualisation of a social justice approach and the FoK framing into a productive relationship with each other so as to inform the adapted teaching practices of the teachers. Over a 2-year period, teachers from different school contexts serving students from low-income areas, committed to a PLC process and met weekly to dialogue about their current teaching practices and, drawing on Fraser's conceptualisation of a socially just teaching orientation and the FoK framing, consider alternative approaches to teaching and learning. Situated within the CAPS, the focus of the PLC discussions was not aimed at working outside of, or undermining, the CAPS framing but rather at finding ways within the CAPS to explore spaces of intervention and possibilities of change to promote educational engagement for all students, particularly those from low-income environments.

The article draws on Bourdieu's thinking tools of habitus, field, and doxa to consider the nature of teachers' pedagogical learning and adaptation, which is conceptualised as a form of "habitus engagement" (Feldman \& Fataar, 2014). Habitus engagement suggests that adapting or changing teachers' pedagogy must contend with the durability of the teachers' pedagogical dispositions, which have formed over time. I describe these embodied pedagogical dispositions as the teachers' "pedagogical habitus," which informs the manner in which they enact their teaching practices. Central to my discussion is the role that PLCs can play in adapting teachers' pedagogical orientations to include a more enriched teaching platform in order to augment and challenge the current narrow CAPS orientation.

\section{South African Schooling}

Germane to the broader discourses that framed the manner in which the PLC was established, is an understanding of the current South African curriculum. In response to a South African schooling system and curriculum that has been described as widening the gaps in performance between schools in deprived areas and those in more privileged environments (Fleisch, 2008), the CAPS was implemented in March 2011 with the aim of shifting curriculum policy focus to a controlled transfer of knowledge and learning-in an attempt to meet the basic educational needs of learners in impoverished circumstances. The CAPS is based on the argument that students from disadvantaged socioeconomic backgrounds learn better from a more structured, teacher-directed mode of pedagogy (Ramatlapana \& Makonye, 2012 citing Lubienski, 2003), and includes strong classification and framing (Bernstein, 1975 ) that is meant to make curriculum knowledge visible and explicit to all students. Subject topics and concepts to be taught are clearly delimited and the pacing and sequencing of the curriculum content is explicit. The CAPS is further accompanied by results-driven assessment requirements that necessitate that Annual National Assessments (ANAs) are written by all schools in Grades 3, 6, and 9 as well as a National Senior Certificate (NSC) examination at the end of students' 12 years of formal schooling.

The CAPS, which is presented as a prepackaged curriculum, is criticised as encroaching on and restricting teacher autonomy and professionalism (Msibi \& Mchunu, 2013; Ramatlapana \& Makonye, 2012). The emphasis on the use of Department of Basic Education (DBE) workbooks and textbooks, and a tightly scripted curriculum designed ostensibly to improve the educational quality of teaching in schools (Spreen \& Vally, 2010), has produced an educational regime that is prescriptive and demands uniformity in curriculum implementation across South African schools, and which is strictly monitored by governmental officials. Fataar (2012) stated that the CAPS is framed on a deficit assumption that South African teachers are poorly prepared and require the strict regulatory regime that governs curriculum implementation. Msibi and Mchunu (2013), discussing the relationship between curriculum revision and the ongoing systematic failure of education in South Africa, suggested that the CAPS indicates that government has given up on the professional agenda of the post-1994 dispensation by making teachers more powerless and unimportant. 
Key to the focus of this article is that the CAPS as a policy orientation, and with its narrow focus on teaching and learning, leaves little pedagogical space for an enriched and critical perspective in education-or opportunity for socially engaging pedagogy to be established (Fataar, 2012). The focus in the establishment of a PLC within the current South African schooling context was, therefore, on creating a platform for teachers from different school contexts to consider an approach to teaching and learning that enables teachers to work across different knowledge forms to provide all students access to the school knowledge code. This rests on the concern that more than 20 years into South Africa's democracy, despite significant educational policy changes, there still exists a deep divide between the functioning of low-income schools and those that operate in the wealthier, leafy green suburbs. Schooling for the diverse student population remains a vastly uneven experience and poverty, race, gender, and religion in many instances continue to delimit the different educational experiences of most South African children (Christie, 2008, p. 4). For many young people, democracy has not brought about better prospects in education. Eradicating or reducing the inequalities of the past within the South African context remains an elusive and ongoing challenge for all involved in education. Structural changes that have high symbolic value are easy to make, however, actually changing the core of teaching and learning practices relies on teachers (Elmore, 1996). Christie noted:

The challenge is not to view what exists as inevitable and unchanging-and not to underestimate the task of changing what exists. The task is to keep envisaging alternatives, to keep challenging with new ideas, and to keep pressing against the boundaries of common sense towards something better. The task is always to hold an ethical position on education, which entails a commitment to continuously thinking about how we may best live with others in the world we share. As educators, our task is to enrich debates from within educational discourses. $(2008$, p. 216)

The focus of the PLC conversations was centred on the teachers reflexively finding ways, within the current scripted and regulated CAPS curriculum framing, to build on Christie's (2008) invitation to envisage alternatives, challenge with new ideas, and continually press against the boundaries of the status quo towards something different, something better.

\section{The Establishment of a Professional Learning Community}

The establishment of the PLC for pedagogical adaptation and change emerged out of an Honours module offered by the university and called Education and Society. The Honours class consisted of approximately 20 students of whom 15 were full-time teachers working mostly in low-income school environments; the other five students were postgraduate students preparing to enter the teaching profession. The Honours class met biweekly for 3 hours over a 6 -month period. This format allowed for an in-depth and engaging discussion on the module focus, which included, among other things, issues of social justice to inform the teachers' pedagogical engagement with their students and teaching contexts. Working within the constraints of the scripted South African CAPS, the module provided the teachers with an understanding of the complexity of teaching within a diverse schooling environment and challenged them to develop both conceptual and pragmatic pedagogical approaches that would enrich their teaching repertoires.

At the completion of the university module, five teachers from the Honours module voluntarily formed a PLC, facilitated by the author, as part of a research project that was run from the university. ${ }^{2}$ The focus of the research was on eliciting teachers' pedagogical learning and adaptation in accordance with a socially just teaching orientation within a PLC. The dialogue within the PLC thus centred on the teachers' reflexive consideration of pedagogical adaptation and innovation in light of the demands and

2 In terms of the research project, ethical clearance was granted by the university and permission to visit and spend time in the schools was given by the Western Cape Education Department. 
challenges the teachers faced in the implementation of the CAPS curriculum. The establishment of the PLC, which met weekly over a 2-year period, was motivated by a desire to continue the conversation initiated during the Honours class, which had challenged the teachers to expand their pedagogical repertoires to include a more engaging pedagogical approach that invited all students into productive interaction with the school knowledge code. The teachers were invited to embark on a voluntary action research journey facilitated primarily via the PLC discussion that focused on their classroom pedagogies and student relationships, rather than the measurable outputs of their students.

The exemplifying basis of this article is the deliberations with the teachers from different school contexts in the weekly PLC meetings, individual interviews with the teachers, and observational school visits that took place over a 2-year period. To ensure the validity and reliability of the data, that is, whether the interpretation of the data is a true reflection of the participant's reality, the PLC meetings and individual interviews were recorded and transcribed by the author and the emerging themes were discussed and verified with the PLC participants (Merriam, 2009). During observational school visits, written notes were recorded by the author and were discussed with the teacher after the lesson, and the teacher's notes and observations were added to provide "thick descriptions" (Merriam, 2009, p. 229) of the adapted classroom lesson. The data themes that emerged over the 2-year PLC process were analysed and discussed with the PLC participants, thus ensuring credibility and trustworthiness of the research findings (McGregor \& Murnane, 2010).

All except one of the teachers had begun their teaching careers during the previous six years, with one teacher beginning her teaching career on completion of the Honours module. Three of the teachers (one woman and two men) had completed a 4-year Bachelor of Education programme in intermediate phase teaching, and two of the teachers (both women) had completed a Post Graduate Certificate in Education (PGCE) for teaching Grades 10-12. All the teachers were enthusiastic about their teaching and indicated that their intentions were to remain in teaching and pursue further studies in education. The teachers gave different reasons for joining the PLC, stating:

I like the platform that the PLC offers me in terms of teachers getting together to learn and to reflect together and critically examine my teaching. After the Honours class I wanted to find ways to use what I had learned in my studies, in my teaching. (Primary school teacher)

The PLC group for me is a place of support and learning as a novice teacher . . as a beginner teacher I need to be able to talk about the daily challenges I face . . . and learn how to do things differently. . . I do not get the opportunity to do so at school. (Primary school teacher)

The togetherness of this PLC group serves as a foundation for me to learn and move towards finding solutions instead of being confined by my school situation, especially the poor situation where I find myself teaching. (Primary school teacher)

I like the idea of sharing together and talking about what I am doing in my teaching, talking about changes I am making and how hard it is ... it makes me feel like I am not working alone ... at my school I am working in isolation, my colleagues and I, we don't talk to each other. (High school teacher)

All the teachers taught in working-class school contexts and described their pedagogy as tightly scripted by the CAPS and the textbooks prescribed by the DoE-as one teacher noted, "you feel like you just have to follow the CAPS, you can't do anything else." They considered the PLC an opportunity to reflect on their current teaching and their students' learning and, building on their learning in the 
Honours module, to find ways in which they could enrich their pedagogy by connecting school knowledge to their students' lifeworld knowledge. The recurring issue that all the teachers struggled with was student disinterest and disengagement in the school learning process. One of the teachers who taught Grades 10-12 students stated:

\begin{abstract}
At high school level, and at our school, so many of the children are just not interested in any of their school work, and they don't do their homework or study and they cause problems in the class ... you end up with so many discipline issues. Dealing with this takes up teaching time ... it is like a vicious cycle that I can't get out of. I am tired of fighting to get the kids to learn.
\end{abstract}

As part of a research project, I conceptualised the PLC as a vehicle for exploring the participating teachers' pedagogical adaptations in light of the scripted CAPS curriculum. I was motivated by a desire to develop a space for professional learning to expand the teachers' pedagogical repertoires. As a form of habitus engagement, the intention of the pedagogical learning that I facilitated via the PLC dialogue was to actively engage with the firmly established teacher identities, educational practices, and classroom pedagogical processes.

The importance of PLCs in generating teacher learning and change in South Africa is underscored by a government document (see Department of Basic Education, 2011) that states that one of its essential aims is to strengthen teacher professionalism by establishing PLCs within each school by 2016/17. A further document on the Department of Basic Education (DBE) website, titled "Action Plan to 2019: Towards the realisation of Schooling 2030," presents PLCs as a strategic goal for improving "the professionalism, teaching skills, subject knowledge and computer literacy of teachers throughout their entire careers" and proffers the establishment of PLCs as a priority for "creat[ing] a stronger enabling framework for teacher-initiated professional development activities" (DBE, 2015, p. 3, 35). In discussing the manner in which this can take place, the DBE admits that despite the 2011 document presenting the importance of teachers forming PLCs for the purpose of professional development, with exception of certain groups such as the Association for Mathematics Education of South Africa (AMESA), this initiative has yet "to 'take off' across a wide range of schools" (DBE, 2015, p. 35).

\title{
Professional Learning Communities
}

While there is no universal definition of PLCs, as a broad definition PLCs can be described as an opportunity for teachers to

engage in continual dialogue to examine practice and student performance and to develop and implement more effective instruction practice ... teachers learn about, try out and reflect on new practices in their specific context, sharing their individual knowledge and expertise. (Darling-Hammond \& Richardson, 2009, p. 3)

PLCs are fundamentally about professional and collective teacher learning, with a specific focus on problematising the learning needs and outcomes of the students they teach (Brodie, 2013; Katz \& Earl, 2010; Stoll \& Louis, 2007; Vescio, Ross, \& Adams, 2008). PLCs provide a unique, flexible, and adaptable organisational form that enables schools to respond to the particular needs of their school context.

Lieberman (2007), discussing the concepts, practices, and policies found in international literature on the developing and sustaining of PLCs, stated that PLCs promote the idea of social relationships and a sense of community to support schools as they find ways to respond to the pace of change and the difficulty of continually improving their practices. She further noted, discussing the rapid pace of change, that: 
[w] are beginning to understand that if we are going to deal with the pressures of globalisation (changing demographics, changing work structures, technology and the way people relate to one another), we need new forms for organising people; a new sense of focus and frame for how we look at the problems of reform and improvement; and relationships that are supportive and sustained over time. (Lieberman, 2007, p. 199)

PLCs provide a platform for the growth and nourishment of intellectual ideas and an opportunity for teachers to conceptually and pragmatically find ways to expand their teaching repertoires and refocus on student learning as central to their pedagogical decisions.

In order to theorise the role of PLCs as a form of habitus engagement in adapting and changing teachers' pedagogical practices, I now turn to a discussion on Bourdieu's thinking tools of habitus, field, and doxa. These tools allow me to analyse and explore the role that the reflexive and dialogical PLC process played in shifting or changing the teachers' pedagogical practices.

\section{Theoretical Considerations: Bourdieu's Thinking Tools}

Bourdieu proffered the concept of habitus as a way of understanding one's relational interactions and practices or actions within the social world. Conditioned primarily during childhood, habitus operates as a system of durable, transposable patterns of sociocultural practices or dispositions, our ways of "being, seeing, acting and thinking, or a system of long-lasting (rather than permanent) schemes or schemata or structures of perception, conception and action" (Bourdieu, 2005, p. 43). Bourdieu used the word system here to specifically convey the manner in which one's habitus is a product of one's history, an outcome of one's "socialized subjectivity ... the social embodied" (Bourdieu \& Wacquant, 1992 , p. 127-8). Reay (2004) described the structuring of one's habitus as containing multiple layers that are acquired over time, given the different social contexts or fields that one moves through.

Habitus does not act alone. There exists an iterative relationship between habitus and field in that they are mutually constitutive of each other and are produced and reproduced through social practice. A field, such as the field of education of which the school field is a subsection, is not a static entity but fluid and dynamic. Particular practices within a field, such as a teachers' pedagogy, should not be seen only as a product of a teacher's habitus, but rather as "the product of the relation between the habitus, on the one hand, and the specific social contexts or 'fields' within which individuals act, on the other" (Thompson, 1991, p. 14). In other words, within the schooling context teachers will adapt to, or incorporate into their dispositional and corporeal teaching repertoires, the values and imperatives of the educational fields that they have moved through. I describe these embodied educational dispositions as the teachers' pedagogical habitus.

Pedagogical habitus can be conceptualised as a layer of habitus formation, which includes the teachers' embodied cognitive, dispositional, and corporeal pedagogical practices that, over time, have become grafted on to their primary habitus. Because one's habitus is not a preprogrammed automated response to situations, but rather an internalised unconscious relationship between one's embodied dispositions and a social field (Maton, 2008, p. 51), incorporated into a teacher's pedagogical habitus are embodied social and cultural messages from the field of education that organises and positions them as certain types of teachers and which, in turn, structures their teaching practices in particular ways. For teachers, the underlying practices within the field of schooling have been implicitly structured within their pedagogical habitus from their own schooling experiences and reinforced through their training and subsequent teaching experiences. Over time, they have come to enact their teaching in a particular manner based on their past educational experiences, which they unwittingly perpetuate and reproduce within their classroom practices. Hence, teachers might enact their pedagogy in a way that can be seen as complicit and reproductive. Bourdieu described this as doxa, 
which he stated refers to the practice of accepting specific sets of beliefs or practices as inherently true and necessary without realising that there are alternatives to the status quo (Webb, Schirato, \& Danaher, 2002).

Bourdieu contended that one's dispositions that are embedded in one's habitus are preconscious and are not easily amendable to conscious reflection and modification. One's dispositions, which are both a "state of mind" and "state of the body" (Bourdieu, 1990, p. 68), are found in the corporeal enactment of practices that are performed mostly without conscious reflection. Consequently, any substantial or effective change in the teachers' practices has to contend with the durability of the teachers' pedagogical habitus formation over time and the teachers' relationship with the various social and educational fields in which they are engaged.

Bourdieu acknowledged the reproductive role that habitus and field play "when social and mental structures are in agreement and reinforce each other" (Wacquant, 1998, p. 223). However, he offered the potential for individuals to adapt or change, stating that when individuals face a "confrontation between disposition and positions, which are not mutually adjusted, but may be at odds, discrepant, divergent, even in some sense contradictory . . . innovations may appear" and in this manner, individuals "who are put into question by structures (operating through the positions) are able to challenge the structures, sometimes to the point of remaking it." (Bourdieu, 2005, p. 47) The reflexive PLC conversations, as a form of habitus engagement, were therefore aimed at challenging the teachers' habitus field congruence in order to find ways to generate the possibility of pedagogical adaptation and change.

\section{A Socially Just Approach to Student Learning: The Methodologic of the Professional Learning Community}

In support of a richer notion of classroom teaching and learning, I now turn to a discussion on the methodologic of the PLC process. In establishing the logic on which the PLC process was established, I draw on Hattam, Brennan, Zipin, and Comber's (2009, p. 304) who explained that

[b]y 'methodo-logic', we thus do not mean research methods or even methodology, but rather the logic of an approach for chasing socially just change through research [and dialogue], including guiding principles that underpin decisions and activities in all points and dimensions of the project.

For the established PLC project, the methodologic was founded on Fraser's (1997) conceptualisation of social justice, which emphasises the need to consider the tension between the redistribution of the school knowledge code currently encoded in CAPS, recognition of student sociocultural constructions of identity, and a representation within school knowledge of the lifeworld knowledges that the students bring with them to school. Engaging with the students' lifeworld knowledges is founded on the view that making curricular connections with, and actively engaging, the students' home socialisations, interests, and knowledge is one key way of securing students' intellectual interest in their schooling (see Fataar, 2012). The conceptual underpinning of the PLC was an attempt to bring all three dimensions of a social justice approach into a productive relationship with each other so as to inform the teaching practices of the PLC teachers. This was aimed at providing the PLC participants with a productive set of conceptual resources that informed their teaching in terms of which they would be able to intellectually engage all their students in their schooling.

In response to the complexity of the challenge to engage all students in their learning, the PLC drew on the theoretical framework of the funds of knowledge (FoK) approach (Moll et al., 1992). This 
approach "is based on a simple premise ... that people are competent and have knowledge, and their life experiences have given them that knowledge" (González \& Moll, 2002, p. 625). This framing acknowledges that students' FoK are grounded in their involvement and experiences in the worlds they inhabit beyond the school and values the students' and their families" "historically accumulated bodies of knowledge and skills essential for household functioning and well-being" (González, Andrade, Civil, \& Moll, 2001, p. 116). This approach affords teachers a more accurate understanding of the students' cultural FoK and identity, drawing this into school learning and in so doing validates the students' lifeworld knowledge and life values. The classroom space becomes a hybrid space where the school knowledge and the students' lifeworld knowledge from their homes and communities intersect. This hybrid school learning becomes a "navigating space" where students gain competence and expertise, via their lifeworld knowledge and cultural interests, that allows them to begin to achieve success in the standardised school knowledge requirements.

The point of departure in the PLC process was the view that what is required to enhance the professional agency of teachers within the current regulative teaching environment, which is framed by the CAPS, is a far richer notion of pedagogical practice aimed at engaging all students in their learning. I suggest this type of approach is required in a context such as South Africa where the space for professional dialogue about ways to enrich the teaching and learning at schools has been eroded by the scripted pedagogical approach of the CAPS, which requires very little dialogue among teachers in schools about their actual pedagogies. The PLC was conceptualised as a safe dialogical space where the participating teachers were able to develop the conceptual capacity and intellectual skills to develop a social justice approach to their classroom pedagogy. The socially just PLC focus was motivated by the view that schools should be spaces where "knowledge and talk about pedagogy [are] ... at the core of the professional culture of schools" because it is a focus on pedagogies that engage all students in their learning that "can make a difference to students' academic and social outcomes from schooling" (Lingard, Hayes, \& Mills, 2003, p. 399).

I now turn to a discussion on teachers' shifting and adapting their pedagogical habitus by drawing on Bourdieu's thinking tools to discuss teachers' pedagogical change as a form of habitus engagement facilitated by the dialogical PLC process.

\section{Working with Bourdieu: Towards a Conceptualisation of Teacher Learning within a Professional Learning Community}

The starting assumption of the PLC is that teachers' pedagogical adaptations are exceptionally difficult to shift. Drawing on Bourdieu's theory of practice provides us with a way of understanding both the limits and possibility of the teachers adapting or changing their established teaching dispositions and educational and classroom practices.

A teachers' pedagogical habitus, as a "system of [educational] dispositions" (Bourdieu, 2005, p. 43), structures the manner in which teachers routinely enact their teaching practices. As discussed above, a teacher's pedagogical habitus is formed over time in response to the cultural rules and contexts of the educational fields they have inhabited. As much as teachers' pedagogical habitus is a product of their educational history and predisposes them to respond in a particular manner based on the structures on which their pedagogical habitus was structured, Bourdieu stated that one's habitus can also: 
be changed by history, that is by new experiences, education or training. . . Dispositions are long-lasting: they tend to perpetuate, to reproduce themselves, but they are not eternal. They may be changed by historical action orientated by intention and consciousness and using pedagogic devices. (2005, p. 45)

Bourdieu further noted that when one's habitus encounters conditions or fields that are different to those in which they were constructed:

there is a dialectical confrontation between habitus, as structured structure, and objective structures. In this confrontation, habitus operates as a structuring structure able to selectively perceive and to transform the objective structure according to its own structure while, at the same time, being re-structured, transformed in its makeup by the pressure of the objective structure. (2005, p. 46-7)

What this means for the establishment of a PLC, operating as a social field or objective structure, is that the logic of the dialogue of the PLC, as a form of habitus engagement, holds the potential to restructure (or reorientate) the teachers' pedagogical habitus through their engagement and learning in the ongoing PLC process. Bourdieu warned that "[a]ny dimension of habitus is very difficult to change," but proffered that habitus can be restructured through a "process of awareness and of pedagogic effort" (2005, p. 45-47).

In considering teachers' pedagogical adaptation, I therefore suggest that the PLC provides a platform where teachers, through a process of awareness, are enabled to interrogate the educational structures that have hitherto structured their pedagogical habitus as a form of doxa. A teacher's pedagogical habitus, which is structured by particular educational discourses, beliefs, and assumptions, if not challenged will continue to inform the underlying logic of her or his teaching practices in a manner that is taken for granted-what I describe as the teachers' educational doxa. South African teachers, situated within the current scripted and regulated curriculum framing, tend to conform and accept the CAPS as an educational discourse that informs their practices, not necessarily because they believe that the curriculum framing is in the best interests of their students, but because there does not seem to be another way. As a result, I posit for the role of a reflexive dialogical PLC process acting as a pedagogic device or form of habitus engagement that confronts the teachers' existing pedagogical structures or educational doxa to facilitate a platform that reorientates or restructures the teachers' pedagogical habitus to include a socially just teaching orientation.

The 2-year PLC process, which informs the conceptual underpinning of this article, was facilitated through a process of awareness to bring elements of the conscious and unconscious inculcation of the teachers' habitus formation to the surface in order to consider ways in which the teachers could restructure their pedagogical thinking. This included an awareness of the teachers' taken-for-granted ways of teaching that had become embedded in their pedagogical habitus, and which informed their teaching practices.

During the initial stages of the PLC process, the teachers' dialogue revealed the manner in which they had in effect become "stuck" in a particular form of pedagogical doxa that was based on the implementation of order and discipline as a pedagogical technique, coupled with the need to meet bureaucratic demands and requirements of the CAPS: 
If I am not very strict and control the class they just take over . . all my classes are over $40,42,43$ students . . . so I put up the work and they copy it down . . I tell them this is what you need to know... sometimes it's the only way to survive. (Primary school teacher)

There is just so much pressure to get through the assessment standards . . . so it is discipline, control, teach, and try to get through everything. (Primary school teacher)

I want to engage them, but the kids are used to just coming into the class, writing down the information from the board and being told what to learn ... I would love to talk to my class and link the content they learn in accounting and business studies to their lives so that they don't just learn it rote-like for the exams, but the school expects us to just give them the information and make sure they learn it so they can pass the exams. (High school teacher)

Combined with the issues of big classes and student ill-discipline, the teachers were constrained by the need to adhere to school expectations that controlled the pacing and sequencing of knowledge via the prescribed curriculum and textbooks. Drawing on Bourdieu, I describe this as an adherence to the doxa of schooling. One conforms and accepts a specific set of educational practices, not necessarily because one believes them to be best practice, but because one does not believe there to be another way. Teachers may not even be aware that they are complying with the dominant discourses, but they accept the schooling status quo because the manner in which schooling is transacted aligns with their pedagogical habitus expectations, based on the way things are-or always have been. These doxic pedagogic discourses are often embedded in teachers' habitus and their practices are consequently enacted accordingly.

For the first six months of the PLC, the dialogue struggled to move beyond the constraints that the teachers experienced in their teaching contexts, into productive discussion around the possibility of an adapted pedagogical process. Wanting to shift the PLC dialogue towards new pedagogical possibilities, as the facilitator of the process, I recognised that a cognitivist approach, such as the one I was employing by building on the teachers' theoretical Honours learning, did not engage the teacher's corporeality, their embodiment of the theoretical and conceptual knowledge in the enactment of their classroom pedagogy. This meant that what the PLC dialogue encountered, instead, was an almost achromatic engagement with the teachers' embodied pedagogical habitus and teaching practices, which was unable to drive sustained pedagogical adaptation and change in their pedagogy.

In response to the inertia that the PLC process was experiencing, as the PLC facilitator, I intervened in the process and invited the teachers to meet for a 4-hour PLC discussion during the midyear holiday break. The purpose of this was for the teachers to spend time collaboratively dialoguing about the design of specific lesson units in order to implement the pedagogical adaptations that the PLC teachers dialogued about in the PLC but were unable to sustain in their enacted classroom teaching. By the teachers' own admission, unless carefully thought through and planned for, sustaining adapted teaching strategies was very difficult:

Teaching is very demanding between the school's admin, the pressure for your kids to pass and getting through all the work. I use the textbook for my lesson plans but this is not helping me to adapt my teaching to engage the students I have in my class in the way we have been talking about in the PLC. (High school teacher)

The intervention involved the PLC teachers designing adapted lesson units based on Fraser's social justice conceptualisation and the FoK framework. Understanding that the teachers still needed to work within the pacing and sequencing of the CAPS, the discussion focused on practical ways in which the 
teachers could design lesson units that opened the lesson framing (the way the teachers transmitted the knowledge to their students) at times to include teacher-student discussions, while closing the lesson framing down at other times, allowing the students to record the necessary content information in their books and complete the required written tasks for the CAPS. Discussing the practicalities of the adapted pedagogical approach with an understanding of the constraints of the teachers' school contexts, combined with including the adaptations in their planned lesson units, provided a productive impetus in the PLC dialogue and pragmatic implementation process, going forward.

Changes were not instantaneous and the teachers continued to struggle with adapting the knowledge transfer to include student discussion and making connections to their students' lifeworld knowledges. However, collaboratively planning specific lesson units to include this approach was instrumental in the teachers making more sustained changes to their pedagogy:

Today, instead of giving the class the notes I first sat and talked to them about inflation and money and interest rates and I asked them practical questions about their lives and saving and we talked about how banks worked ... it wasn't in the textbook notes but it is like the textbooks presume that all the kids have parents who explain this to them ... I am determined to allocate a portion of every lesson connecting the content that the kids have to learn to their lives... and listen to their stories, find out about their funds of knowledge like we have been talking about ... today wasn't just a transferring of knowledge it was a real class discussion. (High school teacher)

This week, I let them write about an imaginary legend based on their community... some of them really connected it to their lives and their stories gave me insight into their homes and communities. The kids enjoyed writing the story and wrote much more than usual, usually they hate writing tasks. (Primary school teacher)

I tried a geography lesson where I asked the kids to list the reasons that their families had moved to the city and from their own family stories, they came up with more examples than the textbook even had. Then I told the kids that the information they had come up with was the answer to a question in the exam and they were excited. It was a moment when both me and the kids realised a different way of dealing with school knowledge. (Primary school teacher)

Following the focused intervention, the teachers began to more consistently imagine and implement the possibility of lesson units that reached beyond the knowledge encoded in the prescribed textbooks and workbooks to mobilise and connect the students' lived knowledge into the school knowledge code. Over the ongoing 2-year PLC process, through the teachers' persistence and their willingness to challenge the educational doxa that had hitherto informed their pedagogical habitus, the teachers were able to find a more generative way of drawing the dimensions of Fraser's conceptualisation of social justice and the FoK approach into their classroom teaching. Through the ongoing PLC conversations, combined with the positive and enthusiastic feedback the teachers received from their students when they relaxed their pedagogical frame (the way in which they organised the transfer of knowledge) to include student participation and a representation of the students' lifeworld knowledges in classroom learning, the teachers began to shift and adapt their classroom pedagogies to include a more generative socially just approach.

Based on the discussion above, I therefore suggest that the possibility of adapting or restructuring a teacher's pedagogy is found within the dialectical confrontation provided by the dialogical PLC field (as an objective structure) engaging with the teachers' embodied pedagogical habitus (as a structured structure). In other words, I suggest that the PLC field, as a form of habitus engagement, holds the 
potential to challenge the structures found in teachers' educational doxa that, over time, has structured their pedagogical practices in a particular manner. It is thus, in this manner, that teachers as professional agents of change, can be enabled to challenge the current curriculum discourse to negotiate a more socially just teaching orientation within their current educational practices.

\section{Conclusion}

This article is based on the belief that teachers can become professional agents of pedagogical adaptation, and that this process is best facilitated as a form of habitus engagement within a collaborative and dialogical PLC process. The 2-year PLC process that informs the empirical basis of this article, placed teachers and their pedagogies as central with a focus on a conceptualisation of a social justice approach to teaching and learning. What the PLC sought to leverage was the understanding of ways in which the teachers could create a teaching and learning platform that engaged the lifeworld or socially generated knowledge of students, scaffolding this knowledge into the school knowledge code to capacitate a richer notion of teaching and learning within the current educational implementation field.

Situated within the South African CAPS and schooling context, this article discusses the possibility of instantiating a more meaningful and engaging pedagogy, particularly in schools that service workingclass students. Drawing on Bourdieu's theoretical tools of habitus, field, and doxa to conceptualise teachers' pedagogical adaptation, the article suggests that shifting or changing teachers' pedagogical practices must engage with the teachers' embodied pedagogical habitus because it is here that their pedagogical dispositions reside as a form of educational doxa. Engaging with the teachers' pedagogical habitus, which has been structured over time by the educational fields that they have inhabited, requires pedagogic effort and a bringing to awareness the structures that inform the teachers' enacted pedagogy. I suggest that the dialogical PLC process, as a form of habitus engagement, holds the potential to challenge the pedagogical structures that reside within the teacher's teaching dispositions in order to instantiate a more socially just teaching orientation in the teachers' classroom pedagogies.

Christie, writing on the challenges of closing the gap between the "two education systems" within South African schools, argued that as socially just educators, in the face of the apparent determinism of social structures, we must continually strive towards an

ethics of intellectual rigour [that] challenges students and teachers to build practices of learning and enquiry as habits and dispositions. . . [This] entails [that we are] continually pushing the boundaries of what we know, questioning the certainties, and exploring different worlds of experience. It entails building on existing scholarship, correcting ourselves when we make mistakes, and working to conceptualise possible [and different] futures. (2008, p. 212-213)

I suggest that the PLC process provides an enabling environment that eschews the view of teachers as technicians of the curriculum and places teachers as professionals who are best positioned to work towards creating schools and classrooms that are productive places of learning for all students.

\section{Acknowledgement}

Thank you to Professor Aslam Fataar from Stellenbosch University, and the reviewers of the first draft of this article for their constructive suggestions that informed the writing of the article. 


\section{References}

Bernstein, B. (1975). Class, codes and control, Volume 3: Towards a theory of educational transmission. London, UK: Routledge.

Bourdieu, P. (1990). The logic of practice. Stanford, USA: Stanford University Press.

Bourdieu, P. (2005). Habitus. In J. Hillier \& E. Rooksby (Eds.), Habitus: A sense of place (pp. 43-49). Farnham, UK: Ashgate.

Bourdieu, P., \& Wacquant, L. (1992). An invitation to reflexive sociology. Cambridge, UK: Polity Press.

Brodie, K. (2013). The power of professional learning communities. Education as Change, 17(1), 5-18.

Christie, P. (2008). Opening the doors of learning. Cape Town, South Africa: Juta.

Coleman, J., Campbell, B., Hobson, C., McPartland, B., Mood, A., Winefield, F., \& York, R. (1966). Equality of educational opportunity. Washington, USA: US Department of Health, Education \& Welfare.

Darling-Hammond, L., \& Richardson, N. (2009). Teacher learning: What matters? Educational Leadership, 66, 46-53.

Department of Basic Education. (2011). Integrated strategic planning framework for teacher education and development in South Africa 2011-2015. Retrieved from http://www.education.gov.za/Portals/0/Documents/Reports/Integrated\%20Strategic\%20Plan\%2 0Teacher\%20Dev\%202011-2025.pdf?ver=2015-02-03-110453-033

Department of Basic Education. (2015). Action plan to 2019: Towards the realisation of schooling 2030. Retrieved from http://www.education.gov.za/Portals/0/Documents/Publications/Action\%20Plan\%202019.pdf?v er=2015-11-11-162424-417

Elmore, R. F. (1996). Getting to scale with successful educational practices. Harvard Educational Review, 66(1), 1-26.

Fataar, A. (2012). Pedagogical justice and student engagement in South African schooling: Working with the cultural capital of disadvantaged students. Perspectives in Education, 30(4), 52-75.

Fataar, A., \& Feldman, J. (2016). Dialogical habitus engagement: The twists and turns of teachers' pedagogical learning within a professional learning community. Perspectives in Education, 34(2).

Fataar, A., \& Feldman, J. (in press). Pedagogical habitus engagement in a developing country context: An exploration of one teacher's pedagogical adjustment within a professional learning community. In T. Gale, K. Gulson, and S. Parker (Eds.), Education policy and inequality. Berlin, Germany: Springer.

Feldman, J. (2016). Eliciting pedagogical learning among teachers in a professional learning community (Doctoral dissertation, Stellenbosch University, South Africa). Retrieved from http://scholar.sun.ac.za/bitstream/handle/10019.1/98391/feldman eliciting 2016.pdf?...2

Feldman, J., \& Fataar, A. (2014). Conceptualising the setting up of a professional learning community for teachers' pedagogical learning. South African Journal of Higher Education, 28(1), 1525-1539.

Feldman, J., \& Fataar, A. (in press). Working through the 'hardness' of teachers' pedagogical habitus: Pedagogical learning among teachers in a professional learning community. In K. Brodie \& H. Borko (Eds.), Professional learning communities in South African schools and teacher education programmes. Cape Town, South Africa: HSRC Press.

Fleisch, B. (2008). Primary education in crisis. Cape Town, South Africa: Juta. 
Fraser, N. (1997). Justice interruptus: Critical reflections on the "postsocialist" condition. Cambridge, UK: Cambridge University Press.

González, N., Andrade, R., Civil, M., \& Moll, L. (2001). Bridging funds of distributed knowledge: Creating zones of practices in mathematics. Journal of Education for Students Placed at Risk, 6(1 \& 2), 115132.

González, N., \& Moll, L. C. (2002). Cruzando el Puente: Building bridges to funds of knowledge. Educational Policy, 16(4), 623-641.

Hattam, R., Brennan, M., Zipin, L., \& Comber, B. (2009). Researching for social justice: Contextual, conceptual and methodological challenges. Discourse: Studies in the Cultural Politics of Education, 30(3), 303-316.

Katz, S., \& Earl, L. (2010). Learning about networked learning communities. School Effectiveness and School Improvement, 21(1), 27-51.

Lieberman, A. (2007). Professional learning communities: A reflection. In I. Goodson \& A. Hargreaves (Eds.), Professional learning communities: Divergence, depth and dilemmas (pp. 199-203). Berkshire, UK: Open University Press.

Lingard, B., Hayes, D., \& Mills, M. (2003). Teachers and productive pedagogies: Contexualising, conceptualising, utilising. Pedagogy, Culture \& Society, 11(3), 399-424.

Maton, K. (2008). Habitus. In M. Grenfell (Ed.), Pierre Bourdieu: Key concepts (pp. 49-65). Durham, UK: Acumen.

McGregor, S. \& Murnane, J. (2010). Paradigm, methodology and method: Intellectual integrity in scholarship. International Journal of Consumer Studies, 34(4), 419-427.

Merriam, S. (2009). Qualitative research. A guide to design and implementation. San Francisco, USA: Jossey-Bass.

Moll, L., Amanti, C., Neff, D., \& González, N. (1992). Funds of knowledge for teaching: Using a qualitative approach to connect homes and classrooms. Theory into Practice, XXXI(2), 132-141.

Msibi, T., \& Mchunu, S. (2013). The knot of curriculum and teacher professionalism in post-apartheid South Africa. Education as Change, 17(1), 19-35.

Ramatlapana, K., \& Makonye, J. P. (2012). From too much freedom to too much restriction: The case of teacher autonomy from National Curriculum Statement (NCS) to Curriculum and Assessment Statement (CAPS). Africa Education Review, 9(1), S7-S25.

Reay, D. (2004). 'It's all becoming a habitus': Beyond the habitual use of habitus in educational research. British Journal of Sociology of Education, 25(4), 431-444.

Spreen, C. A., \& Vally, S. (2010). Outcomes-based education and its (dis)contents: Learner-centred pedagogy and the education crisis in South Africa. Southern African Review of Education, 16(1), 3958.

Stoll, L., \& Louis, K. S. (2007). Professional learning communities: Divergence, depth and dilemmas. Berkshire, UK: Open University Press.

Thompson, J. (1991). Introduction. In Language and symbolic power (pp. 1-31). Cambridge, USA: Harvard University Press.

Vescio, V., Ross, D., \& Adams, A. (2008). A review of research on the impact of professional learning communities on teaching practice and student learning. Teaching and Teacher Education, 24, 8091.

Wacquant, L. (1998). Pierre Bourdieu. In R. Stones (Ed.), Key sociological thinkers (pp. 215-229). London, UK: MacMillan. 
Webb, J., Schirato, T., \& Danaher, G. (2002). Understanding Bourdieu. Crows Nest, Australia: Allen \& Unwin. 